\title{
cAMP-Dependent Protein Kinase Mediates Activity-Regulated Synaptic Targeting of NMDA Receptors
}

\author{
F. Thomas Crump, ${ }^{2}$ Keith S. Dillman, ${ }^{2}$ and Ann Marie Craig ${ }^{1,2}$ \\ ${ }^{1}$ Department of Anatomy and Neurobiology, Washington University School of Medicine, St. Louis, Missouri 63110, and \\ 2Department of Cell and Structural Biology, University of Illinois, Urbana, Illinois 61801
}

Chronic activity blockade increases synaptic levels of NMDA receptor immunoreactivity in hippocampal neurons. We show here that blockade-induced synaptic NMDA receptors are functional and mediate enhanced excitotoxicity in response to synaptically released glutamate. Activity blockade increased the cell surface association of NMDA receptors. Blockade-induced synaptic targeting of NMDA receptors did not require protein synthesis but required phosphorylation and specifically cAMPdependent protein kinase (PKA). Furthermore, activation of PKA was sufficient to induce synaptic targeting of NMDA receptors regardless of receptor activity status. These results implicate PKA activity downstream of receptor blockade as a mediator of enhanced synaptic transport or stabilization of NMDA receptors. Synaptic clustering of NR1-green fluorescent protein was observed in living neurons in response to NMDA receptor and cAMP phosphodiesterase antagonists and occurred gradually over the course of a day. This pathway represents a cellular mechanism for synaptic homeostasis and is likely to function in metaplasticity, long-term regulation of the ability of a synapse to undergo potentiation or depression.

Key words: NMDA receptor; synaptogenesis; activity; synaptic clustering; excitotoxicity; subcellular localization; hippocampus; NR1-GFP
The NMDA-type glutamate receptor plays a central role in circuit development, memory formation, and many forms of synaptic plasticity in the mammalian brain. The NMDA receptor is composed of the essential NR1 subunit and one or more of the modulatory NR2A-D and NR3 subunits (Nakanishi, 1992; Seeburg, 1993; Mori and Mishina, 1995). NMDA receptor channel opening requires ligand binding (by presynaptic glutamate release) and removal of $\mathrm{Mg}^{2+}$ block (by postsynaptic depolarization), thus conferring on the NMDA receptor the ability to function as a molecular coincidence detector (Mayer et al., 1984). Through its $\mathrm{Ca}^{2+}$ permeability, NMDA receptor function is linked with many downstream signal transducing pathways in the neuron. The magnitude and kinetics of calcium elevation at the synapse are thought to be major determinants of long-term effects on synaptic efficacy (Lisman, 1989; Abraham and Bear, 1996).

The level of NMDA receptor function at the synapse critically regulates brain function and cell survival. Mice expressing 5\% of normal levels of NR1 exhibit increased motor activity, stereotypy, and deficits in social and sexual interactions, behaviors associated with schizophrenia (Mohn et al., 1999). Deletion of NR1 targeted postnatally selectively to CA1 of the hippocampus results in mice that are viable but deficient in spatial learning and formation of temporal memory (Tsien et al., 1996; Huerta et al., 2000). In contrast, overactivation of NMDA receptors contributes substan-

\footnotetext{
Received Jan. 30, 2001; revised May 1, 2001; accepted May 1, 2001.

This work was supported by National Institutes of Health Grant NS33184 and the Pew and Markey Charitable Trusts. We thank Huaiyang Wu and Anna S. Serpinskaya for excellent technical assistance, Anuradha Rao for intellectual input, and members of the Craig laboratory for comments about this project. We thank Shaowen Bao and Celine Auger of the MBL Neurobiology course for assistance in generating the NR1-GFP construct.

Correspondence should be addressed to Ann Marie Craig, Department of Anatomy and Neurobiology, Washington University School of Medicine, 660 S. Euclid, Campus Box 8108, 958 McDonnell Sciences Building, St. Louis, MO 63110. E-mail: acraig@thalamus.wustl.edu.

Copyright (C) 2001 Society for Neuroscience $0270-6474 / 01 / 215079-10 \$ 15.00 / 0$
}

tially to neuronal death during epilepsy, stroke, trauma, and neurodegenerative disorders (McDonald and Johnston, 1990; Choi, 1994; Rothman and Olney, 1995; During et al., 2000).

NMDA receptor function is regulated during development and by experience, through changes in subunit expression, phosphorylation, and association with modulatory proteins. More recently, it has become clear that regulation of synaptic receptor function can also occur through regulation of subcellular targeting of receptors. This mode of regulation has been studied most intensively for the AMPA-type ionotropic glutamate receptor. Accumulating evidence suggests that synaptic AMPA receptors undergo continuous recycling and that enhanced endocytosis may contribute to long-term depression and enhanced membrane insertion may contribute to long-term potentiation (Luscher et al., 1999; Noel et al., 1999; Shi et al., 1999). Regulation of synaptic targeting of NMDA receptors has not been reported on a short time scale, but evidence suggests that such regulation may occur developmentally and in response to long-term activity changes. We reported previously that long-term pharmacological blockade of NMDA receptor activity enhanced synaptic localization of NMDA receptors in cultured hippocampal neurons (Rao and Craig, 1997; see also Liao et al., 1999).

We show here that increased synaptic levels of NMDA receptor as a consequence of long-term blockade result in enhanced excitotoxicity. Thus, paradoxically, although short-term treatment with NMDA receptor antagonists protects against toxicity, chronic pretreatment enhances toxicity. We show further that blockade-induced NMDA receptor redistribution to the synapse occurs without new protein synthesis but requires phosphorylation and is specifically regulated by cAMP-dependent protein kinase (PKA).

\section{MATERIALS AND METHODS}

Cell culture. Low-density hippocampal neuronal cultures were prepared from $18 \mathrm{~d}$ embryonic rats as described in Goslin et al. (1998). Briefly, 
hippocampi were dissociated by trypsin treatment and trituration and plated on poly-L-lysine-coated glass coverslips in $60 \mathrm{~mm}$ culture dishes at a density of 2400 cells $/ \mathrm{cm}^{2}$. After plating, the coverslips were incubated neuron side up for 3-4 hr to allow cells to attach before transferring neuron side down for maintenance into serum-free MEM with N2 supplements above a glial feeder layer. Paraffin-wax dots on the neuronal side of the coverslips separated coverslips from glia. Pharmacological agents were used as indicated at the following concentrations: APV (100 $\mu \mathrm{M}$; RBI, Natick, MA), MK-801 (7.5 $\mu \mathrm{M}$; Alexis), NMDA (2.5 $\mu \mathrm{M}$; Alexis), picrotoxin (PTX; $100 \mu \mathrm{M}$; Calbiochem, La Jolla, CA), tetrodotoxin $(0.5 \mu \mathrm{M}$; Sigma, St. Louis, MO), staurosporine (100 nM; Calbiochem), cycloheximide (5 $\mu \mathrm{M}$; Calbiochem), puromycin (0.5 $\mu \mathrm{M}$; Calbiochem), IBMX (25 $\mu \mathrm{M}$; Calbiochem), 8-bromo-cAMP (10.0 $\mu \mathrm{M}$; Calbiochem), and KT5720 (2.0 $\mu \mathrm{M}$; Calbiochem). Chronic treatments were generally begun at $7 \mathrm{~d}$ in culture, with addition of the drug twice weekly, and the neurons were analyzed at $17-30 \mathrm{~d}$ as indicated.

Immunocytochemistry and quantitation. For experiments involving NMDA receptor or PSD-95 immunocytochemistry, neurons were simultaneously fixed and permeabilized in methanol for $10 \mathrm{~min}$ at $-20^{\circ} \mathrm{C}$, then rinsed in PBS with $0.02 \%$ Triton X-100. Coverslips were blocked in $10 \%$ BSA in PBS and incubated with primary antibodies in 3\% BSA in PBS overnight at $20^{\circ} \mathrm{C}$. Double-label immunostaining was done with combinations of rabbit anti-synaptophysin (G95, 1:8000; gift of P. DeCamilli) and mouse antibodies against NR1 (PharMingen, San Diego, CA; 0.1-3 $\mu \mathrm{g} / \mathrm{ml}$, depending on the lot) or PSD-95 (6G6-1C9; Affinity Bioreagents; $6.0 \mu \mathrm{g} / \mathrm{ml}$; also cross-reacts with other PSD-95 family members). Immunolabeling was visualized with biotinylated anti-mouse secondary antibody and Texas Red-avidin, along with fluorescein-conjugated antirabbit secondary antibody (Vector Laboratories, Burlingame, CA, or The Jackson Laboratory, Bar Harbor, ME; 2.5-7.5 $\mu \mathrm{g} / \mathrm{ml}$ ). Coverslips were mounted in Tris-HCl, glycerol, polyvinyl alcohol with $2 \%$ 1,4-diazabicyclo[2,2,2]octane.

Fluorescent and phase-contrast images of cells were captured on a Photometrics series 200 or Sensys cooled charge-coupled device (CCD) camera mounted on a Zeiss Axioskop microscope with $63 \times, 1.4$ numerical aperture (NA) lens using Oncor or Metamorph imaging software. For quantitation, CCD images were background subtracted, flat-field divided, and interactively thresholded to define clusters. A single threshold was chosen manually for each channel for each image so that clusters (NR1, PSD-95, or synaptophysin) corresponded to puncta of at least twofold greater intensity above the diffuse fluorescence on the dendritic shaft. To count specifically synaptic clusters, a binary mask of synaptophysin puncta was dilated by one pixel around each puncta, and each NR1 or PSD-95 cluster was classified as synaptic if there was any pixel overlap with the dilated synaptophysin image. Measurements were analyzed using Microsoft Excel, StatView, and CricketGraph. Images were prepared for printing using Adobe Photoshop. For quantitation of synaptic localization, generally $10-15$ neurons each from three to four coverslips per culture, three to five cultures each condition were randomly selected on the basis of healthy morphology using phase-contrast or synaptophysin staining and scored to determine the percentage of clusters expressing each combination of antigens.

Chymotrypsin treatment and Western blot analysis. Neuronal cultures were analyzed for surface NR1 by chymotrypsin protease treatment and Western blot essentially as described by Hall and Soderling (1997). Neurons were washed twice with warm HEPES-buffered saline solution, incubated in $1 \mathrm{mg} / \mathrm{ml}$ chymotrypsin in saline solution for $10 \mathrm{~min}$, and then washed three times in saline solution plus $2 \mathrm{~mm}$ PMSF to inactivate the chymotrypsin. The chymotrypsin-treated neurons versus sister neurons not exposed to protease were scraped into warm PBS, pelleted, and resuspended in Laemmli buffer. Generally neurons were pooled from 10-15 coverslips, an aliquot of the lysate was run on a gel to estimate protein concentration, and then the bulk of the sample was used for one to two lanes for Western blot analysis. Sister coverslips were fixed and immunostained for NR1 and synaptophysin to confirm the differential localization of NR1 in the APV-treated group compared with controls. After SDS-PAGE and blotting onto nitrocellulose, paired lanes of control versus APV-treated samples were probed sequentially with antibodies to NR1 (mouse anti-NR1 clone 54.1, PharMingen; $0.5 \mu \mathrm{g} / \mathrm{ml}$ ) and tau (rabbit anti-tau, Sigma; 1:10,000). HRP-conjugated secondary goat antirabbit or anti-mouse antisera (Jackson Laboratory) were used at dilutions of 1:5000, and the signal was visualized using chemiluminescent Super-Signal HRP substrate (Pierce, Rockford, IL) to expose XAR-5 $\mathrm{x}$-ray film. The film signals were digitally scanned, and the signal on the digital image was quantified using NIH-Image densitometric analysis.
Excitotoxicity. Treatment of cells with chronic NMDA-receptor antagonists (7.5 $\mu \mathrm{M}$ MK-801 or $100 \mu \mathrm{M}$ APV) began at $7 \mathrm{~d}$ in culture and was repeated every $3 \mathrm{~d}$ for APV and every $7 \mathrm{~d}$ with MK-801 until the time of experimentation. One coverslip from each dish was incubated in media containing $0.4 \%$ trypan blue at $37^{\circ} \mathrm{C}$ for $5 \mathrm{~min}$ before experimentation. Only cultures with $90 \%$ or higher viability, assayed by exclusion of the dye using phase-contrast and bright-field microscopy, were selected for experimentation. Neurons from each group were transferred into high $\mathrm{K}^{+}$buffer containing (in $\mathrm{mm}$ ): $90 \mathrm{KCl}, 31.5 \mathrm{NaCl}, 2 \mathrm{CaCl}_{2}, 25 \mathrm{HEPES}$, 1 glycine, 30 glucose, for $3 \mathrm{~min}$ and then incubated for $1 \mathrm{hr}$ after insult in conditioned media or conditioned media plus $100 \mu \mathrm{M}$ APV. Coverslips were then incubated in $0.4 \%$ trypan blue in essential media and assayed for viability via microscopy. Cells were required to completely exclude trypan blue to be scored as live. Approximately 150-200 neurons were scored per coverslip, and 8-12 coverslips per group were scored from at least four independent cultures. Sister coverslips used for excitotoxicity analysis were fixed and immunostained for NR1 and synaptophysin to confirm the differential localization of NR1 in the APV- or MK-801pretreated groups compared with controls.

NR1-green fluorescent protein expression and imaging. For live cell imaging experiments, neurons were plated on poly-L-lysine-coated glass coverslips attached via silicone to a hole in the bottom of a tissue culture dish. Glia growing on coverslips with wax dots were suspended above the neurons, and the cultures were maintained in phenol red-free MEM with N2 supplements. Neurons were transfected at plating with NR1-green fluorescent protein (GFP) and NR2A expression plasmids using Effectine reagent (Qiagen, Hilden, Germany) essentially as recommended by the manufacturer. The parent expression plasmids GW1-NR1 and GW1NR2A were gifts of M. Sheng. NR1-GFP was constructed by PCR and consists of NR1C fused at its extreme C terminus with GFPS65A. Transfection conditions were adjusted so that protein expression level per cell was relatively low, estimated at less than or equal to threefold endogenous levels of NR1 assessed by antibody labeling of transfected and neighbor nontransfected cells. Imaging was performed at $15-16 \mathrm{~d}$ in culture on a Nikon TE200 with Prior XYZ stage, Sutter excitation and emission filter wheels, transmitted light shutter, Princeton Micromax 1300 YHS cooled CCD camera, and Metamorph software. The antioxidants $20 \mu \mathrm{M}$ trolox and $60 \mu \mathrm{M} n$-acetyl-cysteine were added before imaging, and $100 \mu \mathrm{M} \mathrm{APV}$ and $25 \mu \mathrm{M}$ IBMX were added after the first time point. For each time point, dishes were removed intact from the $\mathrm{CO}_{2}$ incubator, neurons of interest were relocated and imaged, and dishes were returned quickly to the incubator to prevent changes in $\mathrm{pH}$ of the media. After the final time point, neurons were fixed in paraformaldehyde, permeabilized in Triton X-100, and immunolabeled with rabbit anti-synaptophysin and Texas Red-conjugated secondary antibodies. Neurons of interest were relocated and images were acquired in phase-contrast, GFP, and Texas Red channels with $40 \times 1.3 \mathrm{NA}$ and $100 \times$ 1.4 NA objectives. Average fluorescence intensity per spine and per dendrite shaft was measured on the 16-bit images in Metamorph. Spines did not exactly align between time points because of spine motility, and so the pixel area for measuring spine fluorescence was manually centered over each spine for each image.

\section{RESULTS}

\section{Cell density modulates activity regulation of synaptic NMDA receptor targeting}

We have shown previously that NMDA receptors are not highly clustered at synapses in 3 week, low-density hippocampal cultures and that chronic treatment with tetrodotoxin or with the NMDA receptor antagonist APV causes an increase in the synaptic clustering of the NMDA receptor (Rao and Craig, 1997). Liao et al. (1999) subsequently reported a higher baseline of synaptic NMDA receptor and lesser effect of APV in a similar culture system. One potential difference between these studies was cell plating density. Indeed, we found that a fourfold increase in cell plating density resulted in a significantly higher level of synaptic NR1 detected immunocytochemically under conditions of spontaneous activity (Fig. 1). In the low-density cultures (50K corresponds to 50,000 cells plated per $60 \mathrm{~mm}$ dish), NMDA receptors were detected at high levels at synapses with chronic NMDA receptor blockade but not under conditions of spontaneous activ- 

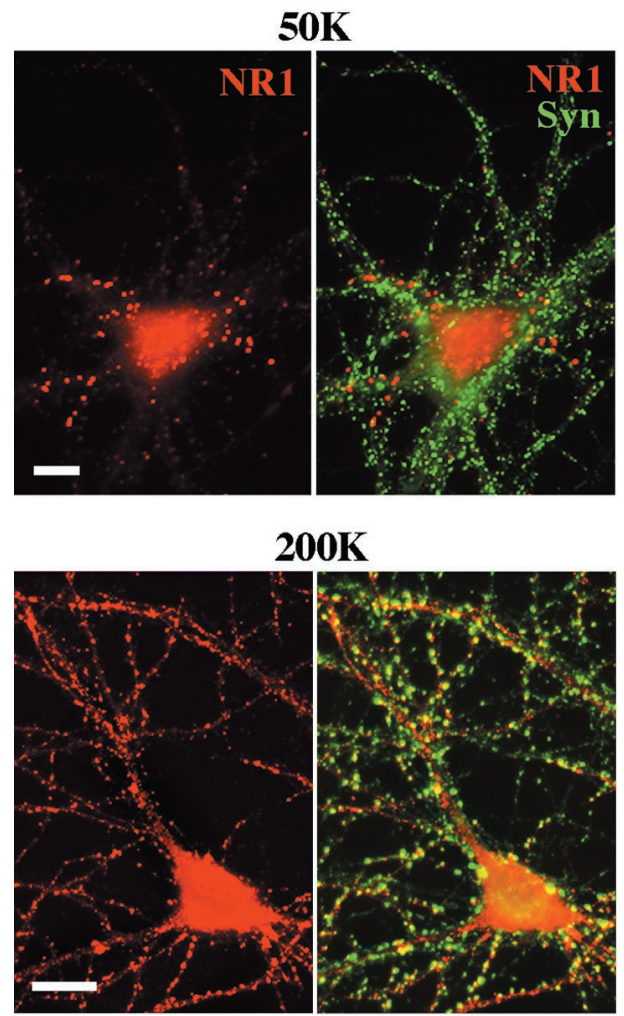

$200 \mathrm{~K}$

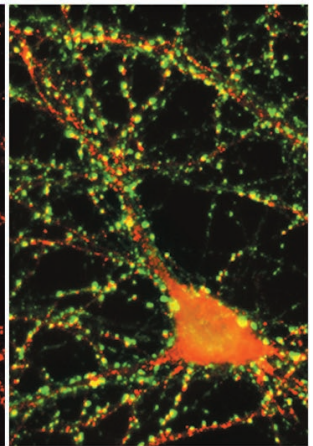

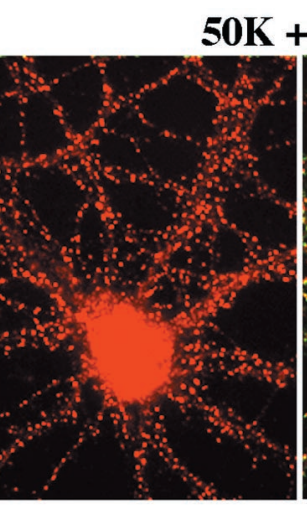
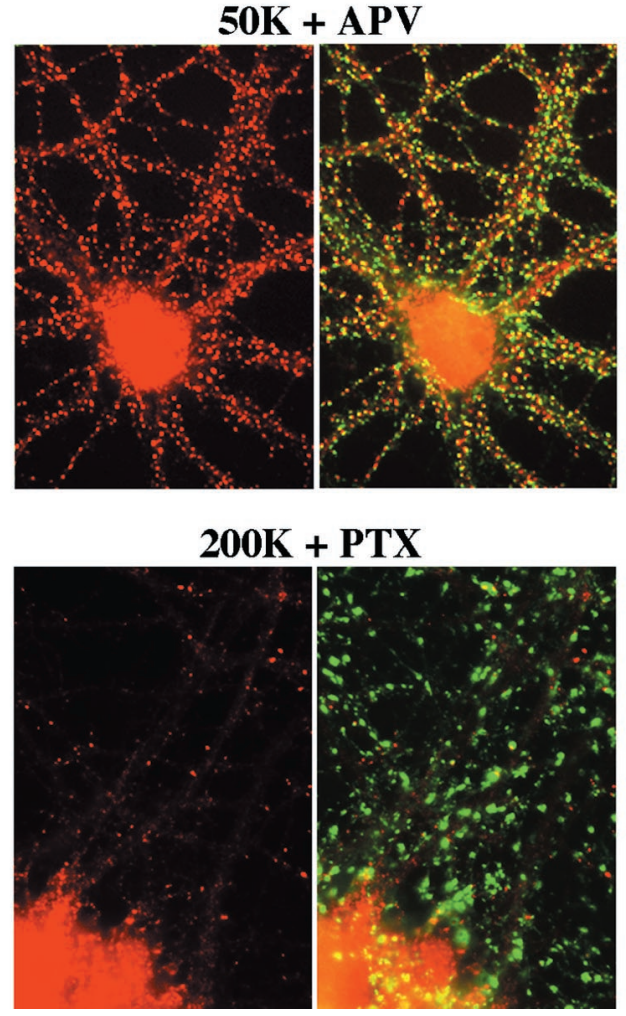
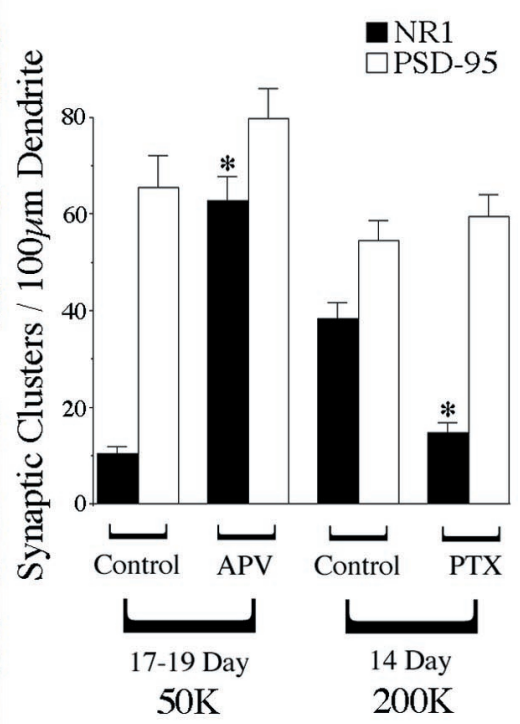

Figure 1. Synaptic clustering of NMDA receptors is regulated by cell density and synaptic activity. Hippocampal neurons were cultured at 50 or $200 \mathrm{~K}$ plating densities $(50,000$ or 200,000 cells per $60 \mathrm{~mm}$ dish) under control conditions of spontaneous activity, or chronically treated with the NMDA receptor antagonist APV or the GABA receptor antagonist picrotoxin $(P T X)$. Neurons shown were cultured for $19 \mathrm{~d}(50 K)$ or $14 \mathrm{~d}(200 K)$ and immunolabeled for NR1 (red) and synaptophysin ( green). In the 50K cultures, control neurons exhibited some nonsynaptic NMDA receptor clusters but few synaptic clusters, whereas APV-treated neurons exhibited numerous synaptic NR1 clusters ( yellow in overlay image). In the 200K cultures, synaptic NMDA receptor clusters were prominent in control neurons but greatly reduced in picrotoxin-treated neurons. Quantitation confirmed that APV treatment induced a significant increase in synaptic clustering of NR1 at $50 \mathrm{~K}\left({ }^{*} p<0.001 ; n=30\right)$ and that picrotoxin treatment induced a significant decrease in synaptic clustering of NR1 at $200 \mathrm{~K}\left({ }^{*} p<0.001 ; n=30\right)$. Neither treatment had a significant effect on synaptic clustering of PSD-95 (images are not shown for PSD-95 labeling; see Fig. 5 for sample image). Scale bars, $10 \mu \mathrm{m}$.

ity. In contrast, in the higher-density cultures $(200 \mathrm{~K}$ corresponds to 200,000 cells plated per $60 \mathrm{~mm}$ dish), NMDA receptor clusters were prominent at synaptic sites under basal conditions of spontaneous activity. Importantly, under these conditions, synaptic targeting of NMDA receptors was still regulated by activity. Inhibition of GABAergic signaling with picrotoxin, which would lead to enhanced excitatory signaling through glutamate receptors, resulted in decreased synaptic targeting of NMDA receptors. Activity specifically regulated synaptic levels of the NMDA receptor and not of the postsynaptic scaffolding protein PSD-95 (Fig. 1). Thus, although cell density modulated baseline levels of synaptic NMDA receptor, under all culture conditions examined synaptic targeting of NMDA receptors was regulated by activity in a homeostatic direction.

\section{Blockade-induced synaptic targeting of NMDA receptors results in enhanced excitotoxicity}

To test whether the NMDA receptors newly recruited to synapses by activity blockade are functional, we examined excitotoxicity in response to synaptically released glutamate. Neurotoxicity was determined in 18-20 d control versus chronic APV-treated or MK-801-treated hippocampal neurons (Fig. 2). Immediately after washout of the NMDA receptor antagonists, toxicity was induced by a 3 min treatment with $90 \mathrm{mM} \mathrm{K}^{+}$-buffered saline to induce synaptic release of glutamate. The depolarization also allows for washout of the voltage-dependent channel antagonist, MK-801
(Huettner and Bean, 1988). After another $60 \mathrm{~min}$ in normal medium, trypan blue exclusion was used to assay cell viability. In contrast to control neurons that exhibited $62.4 \pm 2.8 \%$ cell viability after exposure to high $\mathrm{K}^{+}$, neurons chronically pretreated with APV or MK-801 demonstrated only $36.4 \pm 1.0$ or $39.3 \pm 0.6 \%$ cell viability, respectively $(p<0.001 ; t$ test $;=12)$ (Fig. 2). In all cases, the enhanced toxicity in the APV and MK-801 groups correlated with an increase in synaptic localization of NMDA receptors as revealed by immunocytochemistry for NR1 and synaptophysin. Moreover, the enhanced toxicity was eliminated by inclusion of APV in the 60 min period after insult, the time frame of excitotoxic death attributable to synaptic signaling triggered by the pulse of high $\mathrm{K}^{+}$(Fig. 2, + APV Postinsult) ( $p>0.1$ between groups). Therefore, increased NMDA receptor clustering at the synapse in response to pretreatment with NMDA receptor antagonists increases susceptibility to excitotoxicity.

\section{Activity-regulated synaptic targeting of NMDA receptors is accompanied by an increase in cell surface localization of NR1}

We determined the degree of cell surface localization of NMDA receptors to determine whether increased plasma membrane targeting may contribute to enhanced synaptic localization. Because the available antibodies recognize NMDA receptors only after methanol treatment, which simultaneously fixes and permeabi- 
Excitotoxicity Assay

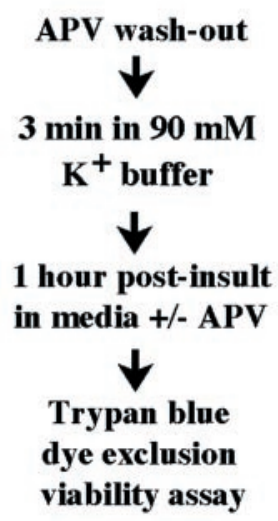

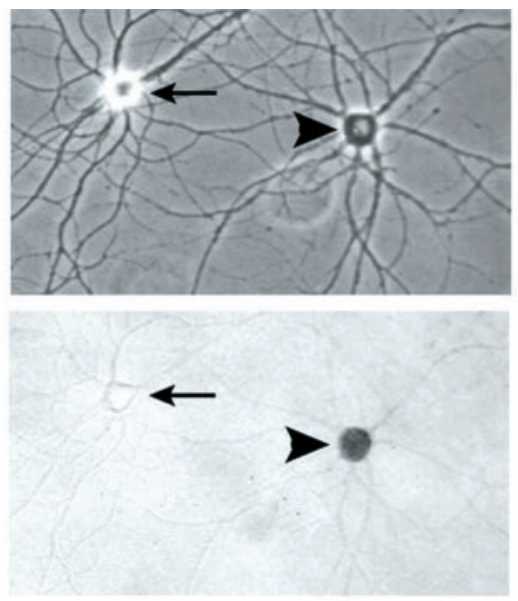

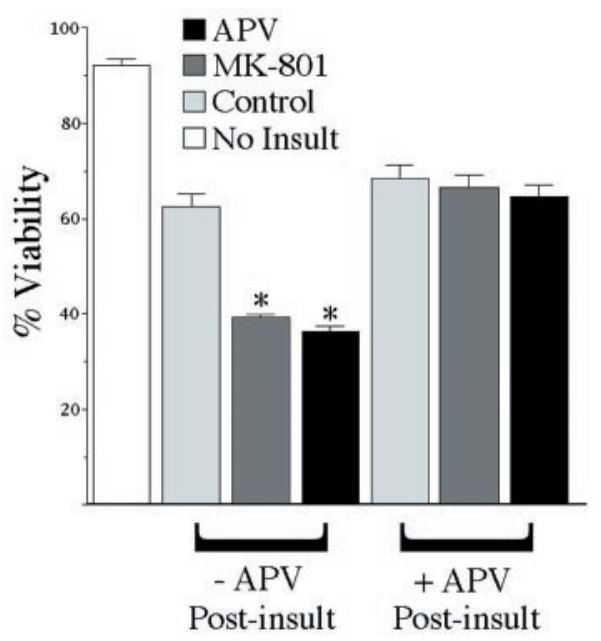

Figure 2. Chronic treatment with NMDA receptor antagonists increases NMDA-dependent neurotoxicity on removal of blockade. Neurons were grown at $50 \mathrm{~K}$ in either control media or media treated chronically with APV or MK-801 and assayed for NMDA receptor distribution and for excitotoxicity at 18-20 d. After washout of chronic drug treatments, neurons were subjected to a short pulse of high $\mathrm{K}^{+}$to induce synaptic release of glutamate and assayed for viability $1 \mathrm{hr}$ later. Sample phase-contrast and corresponding bright-field images indicate live (arrow) and dead (arrowhead) neurons as scored by the trypan blue exclusion assay. One coverslip from each group was tested for viability before inducing toxicity in all cases (No Insult). In contrast to control neurons, which exhibited $62.4 \%$ viability after exposure to high $\mathrm{K}^{+}$and subsequent incubation in untreated media ( $-A P V$ Post-insult), neurons chronically pretreated with MK-801 or APV demonstrated only 39.3 or $36.4 \%$ viability, respectively $\left({ }^{*} p<0.001 ; n=16\right)$. Control, MK-801-, and APV-treated neurons exposed to high $\mathrm{K}^{+}$with subsequent incubation in APV ( + APV Post-insult) did not show a significant difference in excitotoxicity ( $p>0.1 ; n=8$ coverslips). Sister neurons immunolabeled in parallel for NR1 and synaptophysin showed extensive synaptic NR1 clusters in APV and MK-801 pretreated groups but not in controls.

lizes the neurons, we used susceptibility to extracellular protease [as in Hall and Soderling (1997)] to assess surface localization. Control versus chronic APV-treated neurons were exposed to the protease chymotrypsin for $10 \mathrm{~min}$, and then the protease was inactivated and cell extracts were collected and analyzed by Western blot (Fig. 3). APV-treated neurons showed a predominant surface distribution of NR1 (87\% cleavage, average of two experiments). Neurons treated chronically with MK-801 also exhibited a synaptic distribution of NMDA receptors and predominant surface association (data not shown). In contrast, control neurons showed an incomplete surface distribution, with much of the NR1 protected (42\% cleavage, average of two experiments). As a control to indicate inaccessibility of chymotrypsin to the intracellular compartment, the axonal cytoskeletal protein tau showed no proteolytic cleavage. Sister neurons from each experimental group were immunolabeled for NR1 and synaptophysin to confirm enhanced synaptic localization of NMDA receptors in APV-treated neurons compared with controls. Thus, after treatment with NMDA receptor antagonists, NMDA receptors exhibit both enhanced synaptic localization and enhanced surface association.

\section{Activity-regulated synaptic targeting of NMDA receptors does not require protein synthesis}

Chronic APV treatment of hippocampal cultures induces a change in localization of NMDA receptors to a more synaptic distribution and is correlated with twofold increased levels of NR2A and NR2B subunits by Western blot analysis (Rao and Craig, 1997). Although NR2A and NR2B were detected at the nonsynaptic as well as the synaptic clusters, considering the long time course of treatment required to obtain the change in distribution pattern, it seemed likely that new synthesis of NR2 and perhaps other proteins was required for the increase in synaptic localization. To test more directly the role of protein synthesis, we incubated $17 \mathrm{~d}$ cultures with APV in the presence or absence of the protein synthesis inhibitors cycloheximide or puromycin. These protein synthesis inhibitors were toxic by $48 \mathrm{hr}$ but not at $24 \mathrm{hr}$ of treatment. Although a $24 \mathrm{hr}$ treatment with APV induces a lesser increase in synaptic clustering of the NMDA receptor compared with a longer treatment, $24 \mathrm{hr}$ was sufficient to induce a significant change, even with cycloheximide or puromycin cotreatment (Fig. 4). Neither inhibitor of protein synthesis blocked the ability of APV to increase the synaptic clustering of the NMDA receptor (synaptic clusters of NR1 per $100 \mu \mathrm{m}$ dendrite were $9.5 \pm 1.1$ for control, $30.3 \pm 4.3$ for APV, $35.3 \pm 3.1$ for

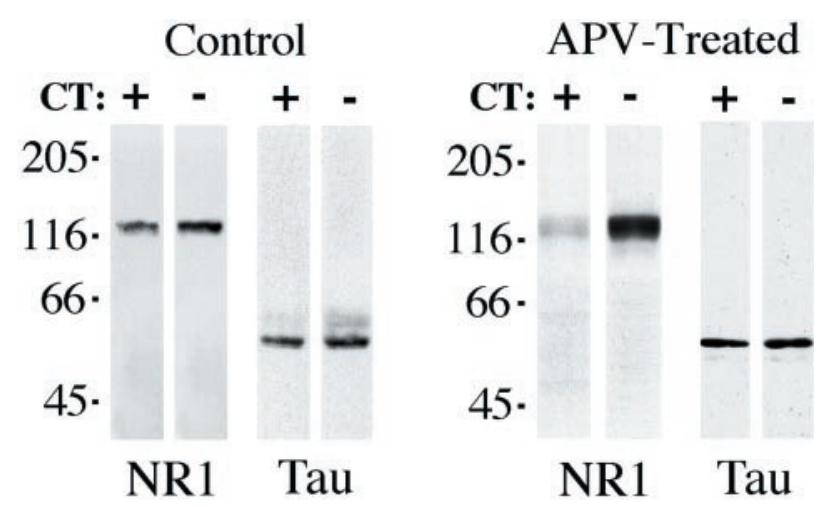

Figure 3. APV-induced synaptic clustering is accompanied by increased cell surface association of NR1. Western blot analysis is shown of control versus chronic APV-treated cultured neuron extracts collected directly $(C T-)$ or after treatment of live cells with chymotrypsin protease $(C T+)$. Chymotrypsin treatment of intact neurons resulted in a partial loss of signal from NR1 full-length bands at $\sim 120 \mathrm{kDa}$ in control neurons ( $42 \%$ cleaved; $n=2$ cultures) and a substantial loss of full-length NR1 in APV-treated neurons ( $87 \%$ cleaved; $n=2$ cultures). Tau, an intracellular microtubule binding protein, was not affected by the chymotrypsin treatment. Immunolabeling of parallel coverslips revealed extensive synaptic clustering of NR1 in APV-treated cultures but not in controls. 

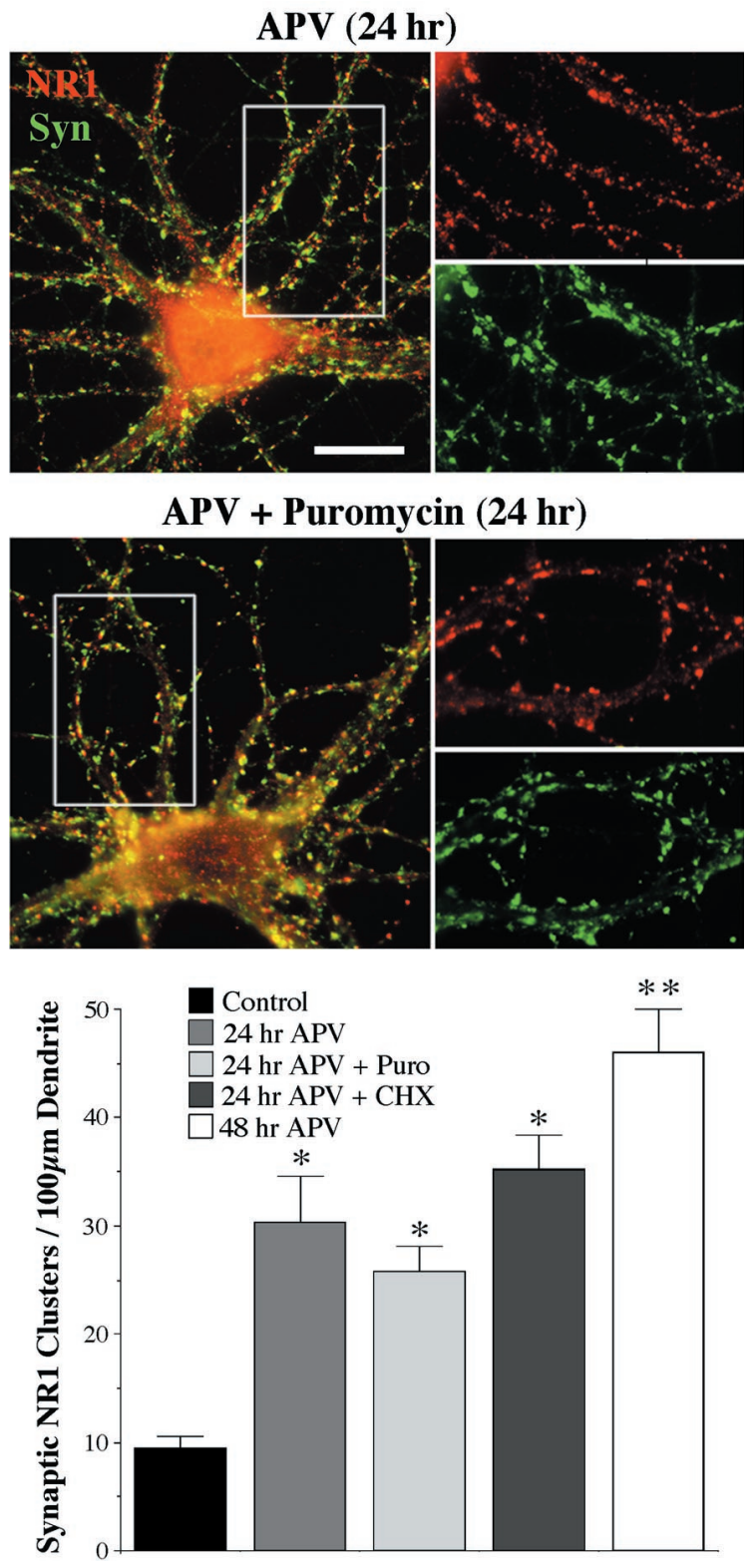

Figure 4. Protein synthesis is not required for APV-induced synaptic clustering of the NMDA receptor. Hippocampal neurons were cultured for $17 \mathrm{~d}$ and then treated with APV alone or with APV plus the protein synthesis inhibitors puromycin or cycloheximide for the indicated times. Neurons were immunolabeled for NR1 (red) and synaptophysin (green). After $24 \mathrm{hr}$ of APV treatment, synaptic fluorescent puncta of NR1 appeared smaller than with chronic APV treatment but greater than in untreated control neurons (compare with Fig. 1, control versus chronic APV). Cotreatment with puromycin did not inhibit the appearance of synaptic NR1 clusters. Quantitation confirmed the ability of $24 \mathrm{hr}$ of APV treatment to induce synaptic clusters of NR1 $\left({ }^{*} p<0.001\right.$ compared with control; ${ }^{* *} p<0.05$ compared with $48 \mathrm{hr}$ APV) and the inability of puromycin or cycloheximide to block this increase $\left({ }^{*} p>0.1\right.$ compared with $24 \mathrm{hr}$ APV). As an additional control for the effectiveness of the drugs, the $24 \mathrm{hr}$ cycloheximide treatment was shown to inhibit synthesis of newly transfected CD $8 \alpha$ by $97 \%$. Scale bar, $20 \mu \mathrm{m}$.

APV plus cycloheximide, and $25.8 \pm 2.3$ for APV plus puromycin; all were $24 \mathrm{hr}$ treatments, $17-18 \mathrm{~d}, n=20-30 ; p>0.1$ for APV +/- inhibitor groups). As a control for the effectiveness of protein synthesis inhibition, cultures were incubated with HSVCD8 $\alpha$ (Craig et al., 1995), a defective herpes virus vector engi- neered to express the lymphocyte protein $\mathrm{CD} 8 \alpha$, in the presence or absence of cycloheximide for $24 \mathrm{hr}$ and then immunolabeled for newly expressed CD8 $\alpha$. Cycloheximide prevented efficient expression of $\mathrm{CD} 8 \alpha$ (749 \pm 133 immunofluorescence units per cell for controls versus $21 \pm 4$ for cycloheximide). Thus, although protein synthesis may contribute in part to the robust accumulation of NMDA receptors at synapses over long time courses, activity-regulated synaptic targeting of the NMDA receptor occurs primarily by a post-translational mechanism.

\section{Synaptic targeting of NMDA receptors requires phosphorylation}

Because phosphorylation is a common post-translational modification, we tested whether phosphorylation is required for the activity-regulated synaptic clustering of the NMDA receptor. Cotreatment of neurons with the broad spectrum kinase inhibitor staurosporine completely blocked the ability of APV to induce an increase in synaptic clustering of NR1 (Fig. 5) (synaptic clusters of NR1 per $100 \mu \mathrm{m}$ dendrite were $11.4 \pm 2.0$ for control, $54.8 \pm$ 5.2 for $48 \mathrm{hr}$ APV, and $4.9 \pm 0.8$ for $48 \mathrm{hr}$ APV plus staurosporine; $17-19 \mathrm{~d}, n=30$; $p<0.001$ for APV versus APV + staurosporine groups). Although synaptic NR1 receptor clusters were lacking after staurosporine treatment, NR1 was still detected in the cell body and in prominent nonsynaptic clusters along dendrite shafts. Thus, inhibition of NMDA receptor channel function requires a kinase activity to induce the translocation of NMDA receptors to synaptic sites or the postsynaptic anchoring of NMDA receptors, or both.

To determine whether kinase activity is required to continuously maintain a synaptic distribution of NMDA receptors, neurons pretreated with APV were exposed to staurosporine in the continued presence of APV. As a starting point, we chose mature chronic APV-treated neurons at $28 \mathrm{~d}$ in culture, which exhibit strong synaptic clustering of NMDA receptors. Addition of staurosporine for $48 \mathrm{hr}$ in the continued presence of APV caused a substantial decrease in synaptic clusters of the NMDA receptor (Fig. 5) (synaptic clusters of NR1 per $100 \mu \mathrm{m}$ dendrite were $85.7 \pm 8.0$ for $48 \mathrm{hr}$ APV and $42.2 \pm 7.2$ for $48 \mathrm{hr}$ APV plus staurosporine; $28-30 \mathrm{~d}, n=20 ; p<0.001$ ). Thus, although kinase activity is not required continuously to maintain some level of synaptic NMDA receptor, it does contribute to maintaining high levels of synaptic receptor over a time course of $2 \mathrm{~d}$.

\section{Synaptic targeting of NMDA receptors is regulated by cAMP-dependent protein kinase}

To determine which kinase activity is required for APV-induced synaptic targeting of NMDA receptors, we coincubated control $17 \mathrm{~d}$ neurons with APV and various protein kinase inhibitors. The most obvious effect was observed with KT5720, an inhibitor of PKA (Fig. 6). KT5720 blocked the ability of APV to induce synaptic targeting of NMDA receptors (synaptic clusters of NR1 per $100 \mu \mathrm{m}$ dendrite were $75.4 \pm 6.1$ for $48 \mathrm{hr}$ APV and $19.0 \pm$ 5.3 for 48 hr APV + KT5720; 17-19 d, $n=20 ; p<0.001)$. These results implicate PKA activity as a mediator of synaptic targeting induced by activity blockade.

To determine whether PKA activity is not only necessary but sufficient to mediate activity regulation of NMDA receptor targeting, we tested agents that activate PKA together with NMDA for effects on NMDA receptor distribution in control $17 \mathrm{~d}$ neurons. Tetrodotoxin induces synaptic clustering of NMDA receptors, presumably by inhibiting glutamate release and thus NMDA receptor activation, and coapplication of NMDA blocks the ef- 

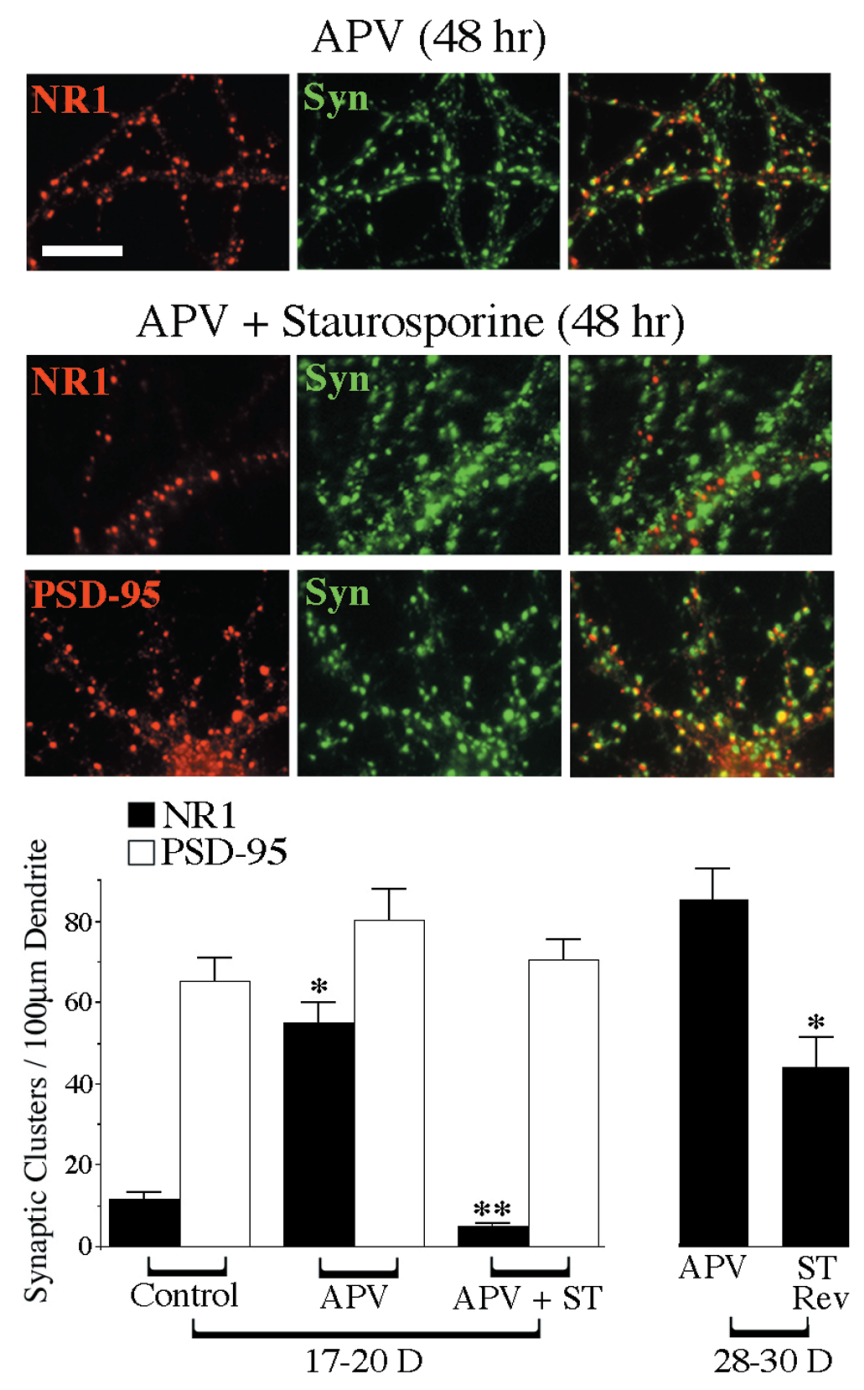

Figure 5. Protein phosphorylation is necessary for APV-induced synaptic clustering of the NMDA receptor. Hippocampal neurons were cultured for $17 \mathrm{~d}$ and then treated with APV alone or with APV plus the broad-spectrum protein kinase inhibitor staurosporine for $48 \mathrm{hr}$. Neurons were immunolabeled for NR1 (red; top and middle) and synaptophysin ( green), or for PSD-95 (red; bottom) and synaptophysin ( green). Although $48 \mathrm{hr}$ APV treatment induced a marked increase in synaptic clusters of NR1 (compare top panel with control $50 K$ cell in Fig. 1), cotreatment with staurosporine strongly inhibited NR1 from clustering at synapses (middle panel). NR1 was often observed in numerous nonsynaptic dendrite shaft clusters with staurosporine cotreatment. In contrast, staurosporine with APV did not affect the synaptic localization of PSD-95 (bottom panel). Quantitation confirmed the increase in synaptic clustering of NR1 with 48 hr APV $\left({ }^{*} p<0.001\right.$ compared with control) and complete inhibition of this effect by staurosporine ( ${ }^{* *} p<0.001$ compared with $48 \mathrm{hr}$ APV). In another set of experiments, $28 \mathrm{~d}$ neurons chronically treated with APV were treated with staurosporine for $48 \mathrm{hr}$ in the continued presence of APV (ST Rev). This resulted in a significant decrease in synaptic clusters of NR1 (graph, right panel; $p<0.001$ ). Scale bar, $10 \mu \mathrm{m}$.

fects of tetrodotoxin (Fig. 6) (Rao and Craig, 1997). Thus it can be inferred that any agent that can induce synaptic NMDA receptor clusters in the presence of NMDA likely functions in the postsynaptic cell downstream of receptor activation. 8-BromocAMP, an agonist of PKA, induced synaptic clustering of NMDA receptors in the presence of NMDA (Fig. 6) (synaptic clusters of NR1 per $100 \mu \mathrm{m}$ dendrite were $10.7 \pm 1.5$ for $48 \mathrm{hr}$ TTX + NMDA and $37.2 \pm 3.8$ for $48 \mathrm{hr}$ 8-bromo-cAMP +
NMDA; 17-19 d, $\mathrm{n} \geq 20 ; p<0.001)$. Furthermore, IBMX, which inhibits cAMP phosphodiesterase and thus raises cAMP levels to activate PKA, dramatically induced synaptic clustering of NMDA receptors in the presence of NMDA (Fig. 6) (synaptic clusters of NR1 per $100 \mu \mathrm{m}$ dendrite were $10.7 \pm 1.5$ for $48 \mathrm{hr}$ TTX + NMDA and 53.9 \pm 4.4 for $24 \mathrm{hr}$ IBMX + NMDA; 17-19 $\mathrm{d}, \mathrm{n} \geq 30 ; p<0.001)$. In fact, a $1 \mathrm{~d}$ treatment with IBMX + NMDA was more effective in inducing synaptic targeting of NMDA receptors than a $1 \mathrm{~d}$ treatment with APV (Fig. 6) (synaptic clusters of NR1 per $100 \mu \mathrm{m}$ dendrite were $28.3 \pm 3.8$ for 24 hr APV and $53.9 \pm 4.4$ for $24 \mathrm{hr}$ IBMX + NMDA; $17-19 \mathrm{~d}, n=$ $30 ; p<0.001)$. IBMX also induced synaptic clustering of NMDA receptors in the absence of added NMDA (data not shown). Thus PKA activation is sufficient to induce synaptic clustering of NMDA receptors regardless of NMDA receptor activity status.

\section{Synaptic targeting of NMDA receptors can be visualized in living neurons and occurs gradually over the course of $1 \mathrm{~d}$}

To visualize NMDA receptors in living neurons, we transfected neurons at low expression level with a green fluorescent proteintagged NR1 subunit, NR1-GFP, along with untagged NR2A. A similar NR1 C-terminal GFP fusion has been found to form functional channels when coexpressed with NR2 subunits in heterologous cells (Marshall et al., 1995), but its localization has not yet been reported in neurons. Hippocampal neurons were transfected at plating and imaged at 15-16 d (Fig. 7). In control neurons, as expected, few spiny clusters were observed; NR1GFP was sometimes not detected in dendritic spines, or more often was detected in spines as well as shafts but not clustered in spines. Occasionally a few shaft clusters were observed; these may have been synaptic or nonsynaptic. After addition of APV and IBMX at $0 \mathrm{hr}$, by $6.5 \mathrm{hr}$ many spines appeared to show a slight increase in NR1-GFP fluorescence. By $23 \mathrm{hr}$ after addition of the NMDA receptor and cAMP phosphodiesterase antagonists, many spines exhibited a pronounced clustering of NR1-GFP. At this time neurons were fixed and immunolabeled post hoc for synaptophysin. The spiny NR1-GFP clusters induced by APV and IBMX were apposed to synaptophysin-labeled boutons, indicating that they were indeed synaptic. Thus synaptic targeting of NMDA receptors was confirmed by visualization of tagged NR1 in individual neurons over time.

Quantitation of the NR1-GFP dendrite spine/shaft fluorescence ratio in sets of individual spines over time revealed a consistent increase in neurons treated with APV plus IBMX but no change in untreated sister neurons (Fig. 8). The NR1-GFP spine/shaft fluorescence ratio varied considerably between individual spines but increased on average more than twofold on treatment with APV and IBMX (from $1.0 \pm 0.3$ to $2.2 \pm 0.7$; paired $t$ test, $p<0.001 ; n=45$ spines from three neurons). This change appeared to be attributable to both an increase in NR1GFP in spines and a decrease in NR1-GFP in shafts. Over the same time course, the NR1-GFP spine/shaft fluorescence ratio remained unchanged in control neurons $(1.0 \pm 0.3)$. A small but significant increase in NR1-GFP clustering was observed even after $6.5 \mathrm{hr}$ of treatment with APV plus IBMX (spine/shaft fluorescence ratio increased from $1.0 \pm 0.3$ to $1.3 \pm 0.5$; paired $t$ test, $p<0.01 ; n=45)$. Thus synaptic clustering of NMDA receptors occurred gradually over the course of $1 \mathrm{~d}$.

\section{DISCUSSION}

We report here functional effects of activity-regulated synaptic targeting of NMDA receptors and an underlying cellular mech- 

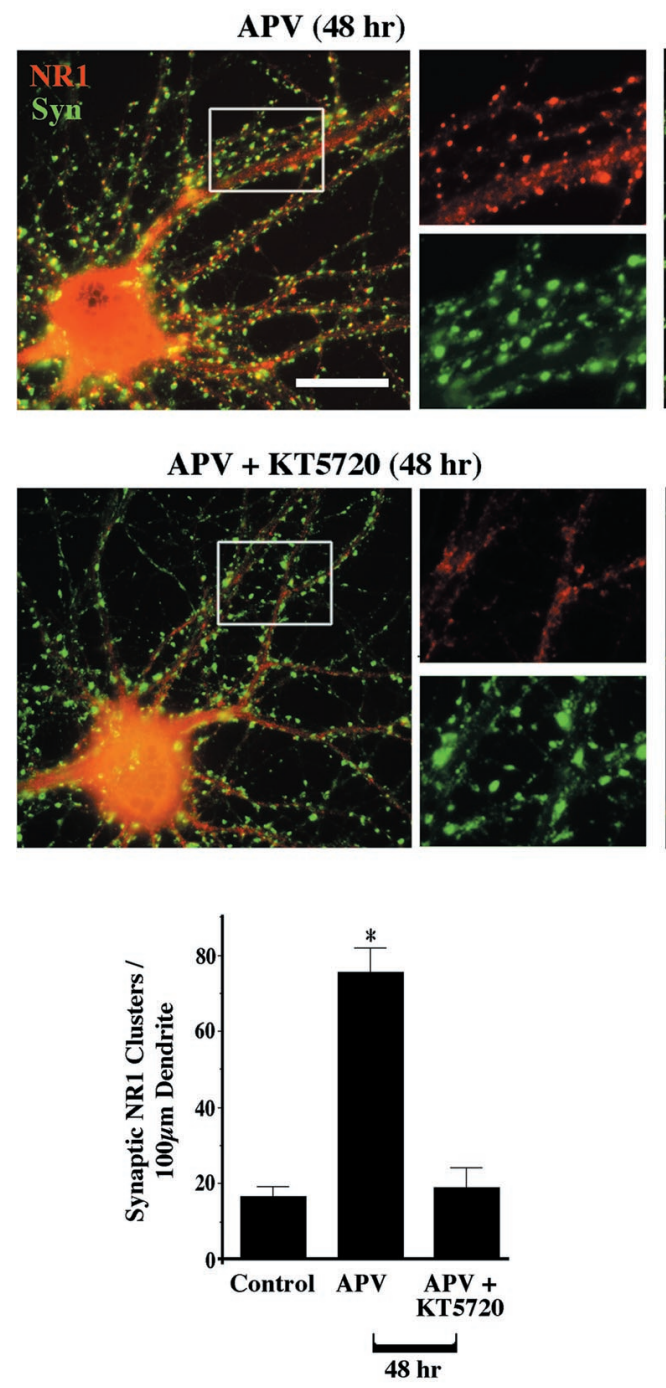

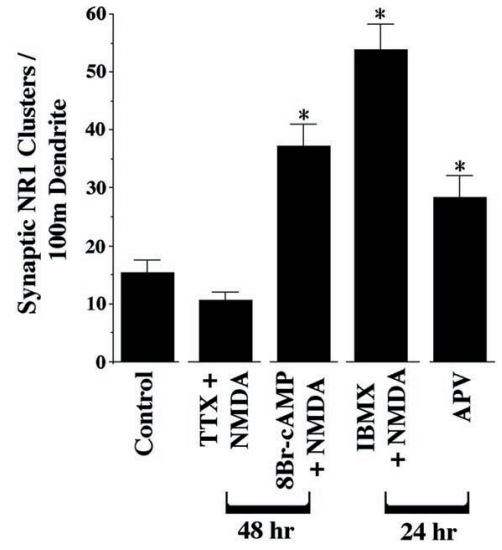

TTX + NMDA (48 hr)
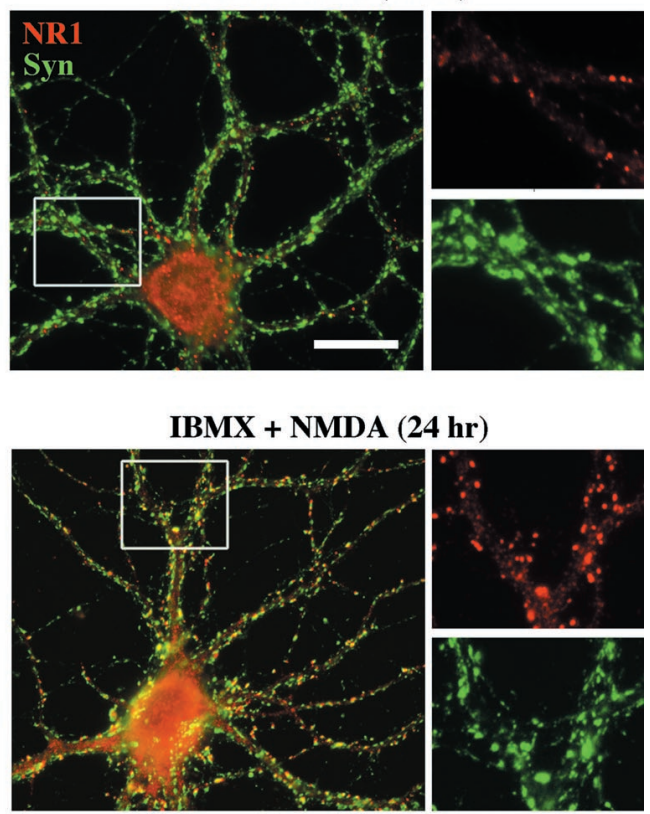
cAMP + NMDA, or IBMX + NMDA
NT5720, TTX + NMDA, 8Brfor 24-48 hr. Neurons were immunolabeled for NR1 (red) and synaptophysin (green). Left panels, Although $48 \mathrm{hr}$ APV treatment induced a marked increase in synaptic clusters of NR1 (compare top panel with control $50 \mathrm{~K}$ cell in Fig. 1), cotreatment with KT5720 strongly inhibited NR1 from clustering at synapses (middle panel). Quantitation confirmed the increase in synaptic clustering of NR1 with 48 hr APV (*p $<0.001$ compared with control) and complete inhibition of this effect by KT5720 $(p<0.001$ compared with $48 \mathrm{hr}$ APV). Scale bar, 20 $\mu \mathrm{m}$. Right panels, Although neurons treated 48 hr with TTX + NMDA exhibited some nonsynaptic but few synaptic clusters of NR1, even $24 \mathrm{hr}$ of treatment with IBMX + NMDA strongly induced synaptic clustering of NR1 (middle panel). Quantitation confirmed the increase in synaptic clustering of NR1 with $48 \mathrm{hr}$ 8 Br-cAMP + NMDA or 24 hr IBMX + NMDA $(* p<0.001$ compared with TTX + NMDA or compared with control). Thus these agents that activate the cAMP pathway induced synaptic clustering of the NMDA receptor even with continued receptor activation. IBMX + NMDA was actually more effective than APV in inducing synaptic clustering of NR1. Scale bar, $20 \mu \mathrm{m}$. anism. In parallel to blockade-induced increases in synaptic clustering in low-density culture as reported previously (Rao and Craig, 1997), enhanced excitatory activity by inhibition of GABAergic signaling resulted in decreased synaptic clustering of NMDA receptors in higher-density culture. Regulated changes in synaptic accumulation of NMDA receptor immunoreactivity resulted in differences in excitotoxicity. In contrast to short-term protective effects, chronic treatment with NMDA receptor antagonists increased synaptic NMDA receptor accumulation and increased toxicity in response to stimulation of synaptic release of glutamate. Chronic receptor blockade increased both synaptic association and cell surface association of NMDA receptors. Increased synaptic accumulation of NMDA receptors could be observed within $1 \mathrm{~d}$ of blockade and did not require protein synthesis. However, blockade-induced redistribution of NMDA receptors to synaptic sites and maintenance of receptors at synapses required phosphorylation. Inhibition of PKA prevented blockade-induced increases in synaptic targeting of NMDA receptors, and activation of PKA mimicked blockade-induced increases in synaptic targeting of NMDA receptors even in the presence of NMDA. Thus PKA acts downstream of receptor blockade to enhance synaptic transport and stability of NMDA receptors. Regulated synaptic targeting of NMDA receptors was visualized in living neurons expressing NR1-GFP, an approach likely to prove fruitful for further studies of NMDA receptor trafficking. Increased synaptic clustering of NR1-GFP was observed by $6.5 \mathrm{hr}$ and was very pronounced by $23 \mathrm{hr}$ after addition of NMDA receptor and phosphodiesterase antagonists. These results indicate a cellular mechanism for a form of homeostatic regulation of synaptic receptor density. Given the central role of NMDA receptors in many forms of synaptic plasticity, this longterm regulation of the level of synaptic NMDA receptor may determine the cellular response in normal physiological as well as pathological conditions.

\section{Mechanisms of activity-regulated synaptic targeting of NMDA receptors}

The long time course of the activity regulation of synaptic targeting of the NMDA receptor initially suggested that a transcriptional increase might be involved. Indeed, activity blockade can increase mRNA and protein levels for NMDA receptor subunits in cortical cultures (Follesa and Ticku, 1996). Although activity blockade did not increase protein levels for NR1 in our hippocampal cultures, we could not previously rule out the possibility 

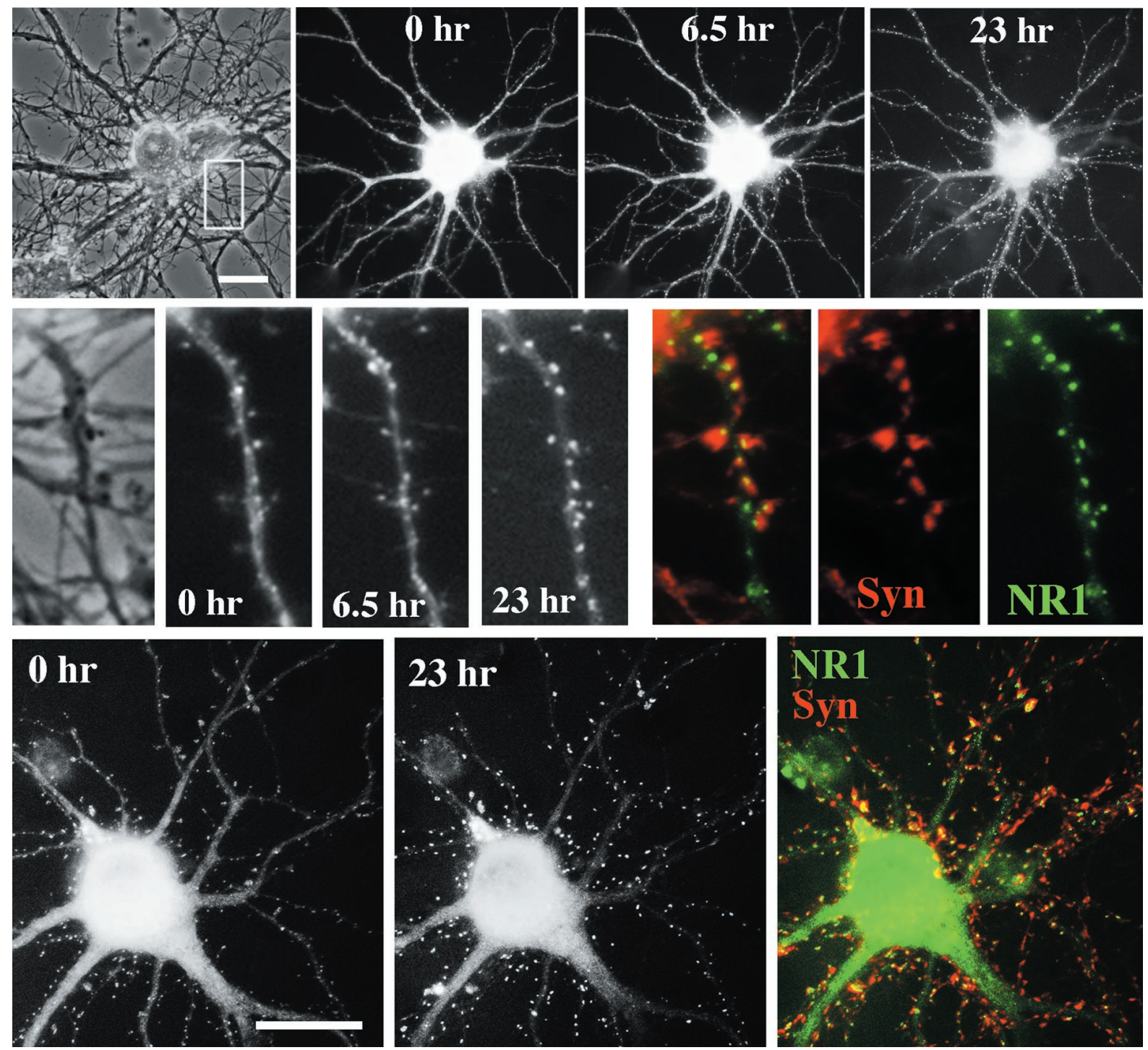

Figure 7. Induction of synaptic clustering of NMDA receptors in living neurons expressing NR1-GFP. Hippocampal neurons were transfected at plating for NR1-GFP and untagged NR2A and imaged at 15-16 d in culture. A series of images are shown in grayscale for NR1-GFP for two cells. After the initial time point $(0 \mathrm{hr})$, APV and IBMX were added. By $23 \mathrm{hr}$, NR1-GFP fluorescence appeared to be increased in dendritic spines and decreased in dendrite shafts. Even at $6.5 \mathrm{hr}$, some spines appeared to show a partial increase in clustering of NR1-GFP. Color panels show NR1-GFP fluorescence ( green) and post hoc immunofluorescence for synaptophysin (red) obtained after fixing the neurons immediately after the $23 \mathrm{hr}$ time point. The clusters of NR1-GFP induced by APV and IBMX were mostly apposed to synaptophysin-labeled terminals. Scale bars, $20 \mu \mathrm{m}$.

that the twofold increase in protein levels observed for NR2A and NR2B might mediate the change in NMDA receptor distribution (Rao and Craig, 1997). However, now we show that a significant redistribution of NMDA receptors from a largely nonsynaptic to a synaptic pattern occurs within $24 \mathrm{hr}$ under conditions of protein synthesis inhibition (Fig. 4). Thus receptor molecules redistribute from somatic and nonsynaptic dendritic pools to the synapse, perhaps by active targeting or perhaps by increased anchoring ability of a binding complex at the synapse. A mainly passive mechanism would be more consistent with the long time course, but further studies will be required to define the precise trafficking/anchoring mechanism.

The simplest hypothesis consistent with our data is that NMDA receptor blockade activates PKA, which increases synaptic receptor targeting by phosphorylation of an NMDA receptor subunit or binding protein. The ability of the PKA inhibitor to block synaptic receptor targeting in the presence of APV and the ability of the PKA activators to induce synaptic receptor targeting in the presence of NMDA (Fig. 6) suggests that PKA functions downstream of activity blockade. Decreased calcium entry through NMDA receptors could potentially activate PKA through decreased activity of a calcium/calmodulin-activated phosphodiesterase of the PDE1 family (Zhao et al., 1997; Kakkar et al., 1999). These enzymes are highly expressed in neurons, including hippocampal pyramidal neurons, are present in the postsynaptic density (Grab et al., 1981), and are targets of the inhibitor IBMX used in this study (Fig. 6).

NMDA receptor subunits NR1, NR2A, and NR2B can all be phosphorylated by PKA and show some basal phosphorylation in hippocampal tissue (Leonard and Hell, 1997; Tingley et al., 1997). However, the consequences of these individual phosphorylation events on receptor trafficking or anchoring or interaction with binding proteins is not known. Initial transport of NMDA receptors to the dendrite and perhaps to the synapse is suggested to 


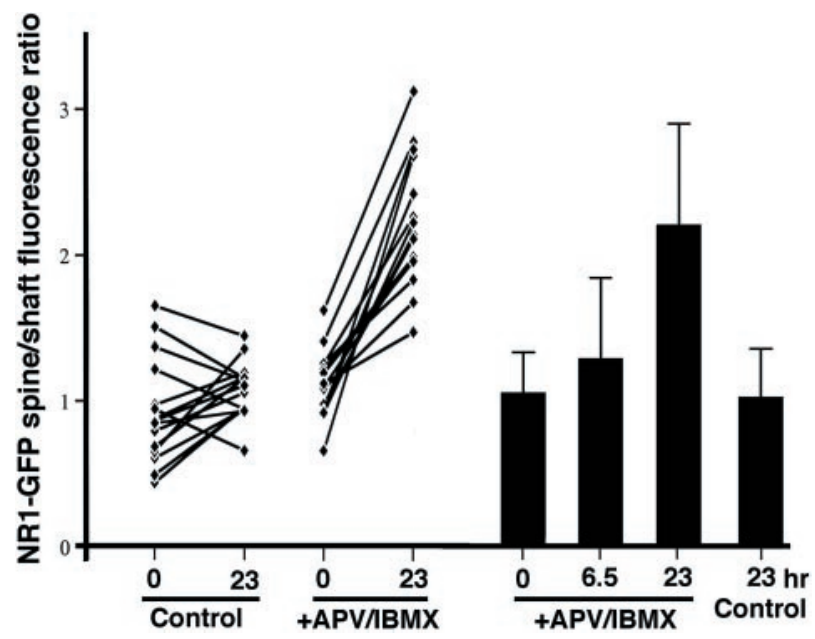

Figure 8. Induction of synaptic clustering of NMDA receptors occurs gradually over the course of $1 \mathrm{~d}$. Hippocampal neurons were transfected with NR1-GFP and NR2A and imaged at 15-16 d in culture for up to 23 $\mathrm{hr}$, with or without addition of APV and IBMX at $0 \mathrm{hr}$, as in Figure 7. The line graphs show the change in NR1-GFP spine/shaft fluorescence ratio in 15 individual spines over time. This ratio consistently increased in the neurons treated with APV plus IBMX but showed only small fluctuations in sister untreated neurons. The NR1-GFP spine/shaft fluorescence intensity averaged from individual dendrite spines followed over time showed a significant increase at $6.5 \mathrm{hr}$ after addition of APV plus IBMX (paired $t$ test; $p<0.01 ; n=43$ spines from 3 cells) and a greater increase at $23 \mathrm{hr}(p<0.001$ compared with $0 \mathrm{hr})$. The fluorescence ratio in control cells was unchanged at the end of the $23 \mathrm{hr}$ imaging period ( $n=45$ spines from 3 cells).

occur by association of NR2B with the tripartate complex of mLin-2/mLin-7/mLin-10, which binds the motor protein KIF17 (Butz et al., 1998; Jo et al., 1999; Setou et al., 2000). KIF17 is a dendritic minus-end-directed microtubule motor that can be purified with NR2. Synaptic anchoring of the NMDA receptor does not require actin filaments or microtubules (Allison et al., 2000) but presumably requires binding of NMDA receptor subunits to other postsynaptic density proteins. Analysis of neurons from mice bearing NR2 genes with $\mathrm{C}$-terminal truncations indicates that the C-terminal domains of NR2A and NR2B contribute to synaptic localization along with additional, as yet unidentified, domains of the receptor (Mori et al., 1998; Steigerwald et al., 2000). Candidate anchoring proteins include the PDZ domain proteins PSD-95, chapsyn-110/PSD-93, SAP102, and S-SCAM (Kornau et al., 1997; Hirao et al., 1998), the actin-binding proteins $\alpha$-actin and spectrin (Wyszynski et al., 1997; Wechsler and Teichberg, 1998), and the AKAP yotiao (Westphal et al., 1999). Interestingly, because yotiao can bring together NMDA receptors and PKA, it may function to further enhance synaptic targeting of NMDA receptors. In vitro the interaction between NMDA receptor $\mathrm{C}$ termini and the binding regions of these putative anchoring proteins or of mLin-7 occurs in the absence of phosphorylation. However, interaction in the neurons may be regulated by phosphorylation-dependent conformational changes to the full-length proteins. For example, the SH3 and GK domains of PSD-95 form an intramolecular association that regulates coclustering of PSD-95 with ion channels in heterologous cells (McGee and Bredt, 1999; Shin et al., 2000). Thus PKA phosphorylation may determine the availability of a key protein-protein interaction domain. Alternatively, synaptic targeting of NMDA receptors may be determined primarily by a protein not yet discovered, the interaction of which with the receptor is dependent on phosphorylation.

\section{Functional implications of activity-regulated synaptic targeting of NMDA receptors}

The excitotoxicity experiments (Fig. 2) demonstrate that the changes in targeting of the NMDA receptor observed immunocytochemically and by protease resistance correspond to functional changes in NMDA receptor-mediated signaling in the neurons. Thus, although acute treatment with NMDA receptor antagonists protects against toxicity, chronic pretreatment enhances toxicity. Consistent with our results, increases in calcium hyperexcitability and seizure-like activity have been reported after chronic glutamate receptor blockade of neuronal cultures (Furshpan and Potter, 1989; Obrietan and Van den Pol, 1995). The APV-induced increase in toxicity may be partially accounted for by the twofold increase in surface association of NR1, but it seems likely that the increased synaptic localization is important. Calcium activation of nitric oxide production through coupling of NMDA receptors to nitric oxide synthase via the scaffolding molecule PSD-95 contributes to the neurotoxicity of NMDA receptor overactivation (Dawson et al., 1991; Brenman et al., 1996; Sattler et al., 1999). The synaptically localized receptors are more likely to be linked through PSD-95 to nNOS and thus are more likely to be effective at mediating toxicity. The association of the majority of synaptic NMDA receptors with dendritic spines is also likely to concentrate the calcium elevation to mediate more effective activation of nNOS compared with NMDA receptors on dendrite shafts.

In addition to pathological conditions of stroke and epilepsy, circuit changes during nervous system development and normal responses to behavioral experience are likely to affect NMDA receptor targeting. Although such regulation has yet to be demonstrated directly in vivo, we have observed regulated subcellular targeting of NMDA receptors under all of the different culture conditions assayed. For example, in higher-density cultures, basal levels of NMDA receptor at the synapse are higher, and NMDA receptors can now be driven away from synapses by enhanced excitatory activity. Furthermore, the effect of manipulating GABAergic signaling (Fig. 1) reinforces the idea that the balance between excitatory and inhibitory input may critically regulate NMDA receptor targeting. This cellular pathway regulating synaptic targeting of NMDA receptors may function in homeostasis or metaplasticity, or both. Turrigiano et al. (1998) have elegantly demonstrated that AMPA receptors undergo homeostatic synaptic scaling. A long-term increase in the excitation level of a cell leads to a global decrease in synaptic AMPA receptor-mediated currents while maintaining differential responsiveness of individual synapses. The effects we observe on NMDA receptors may reflect an independent but similar homeostatic response, selectively regulated by NMDA receptor activity. Such a response could be particularly important because levels of excitatory and inhibitory inputs undergo large changes during development. Homeostatic scaling would also be necessary to keep a neuron within an appropriate response range after Hebbian mechanisms such as long-term potentiation or depression acting at subsets of synapses (Turrigiano, 1999).

Given the function of NMDA receptors as molecular coincidence detectors regulating calcium entry, regulation of the density of NMDA receptors at synapses may be a mechanism for metaplasticity. It has been suggested that the level of calcium entry through the NMDA receptor may determine whether stimulation 
leads to potentiation or depression (Lisman, 1989). Additional evidence indicates that the magnitude and even direction of plasticity in response to a given stimulation are not fixed but change with previous activity (Bear, 1995; Abraham and Bear, 1996). The pathway defined here for activity regulation of NMDA receptor targeting could be one cellular mechanism responsible for this sliding threshold between depression and potentiation, a long-term regulation of the ability of a synapse to undergo modification.

\section{REFERENCES}

Abraham WC, Bear MF (1996) Metaplasticity: the plasticity of synaptic plasticity. Trends Neurosci 19:126-130.

Allison DW, Chervin AS, Gelfand VI, Craig AM (2000) Postsynaptic scaffolds of excitatory and inhibitory synapses in hippocampal neurons: maintenance of core components independent of actin filaments and microtubules. J Neurosci 20:4545-4554.

Bear MF (1995) Mechanism for a sliding synaptic modification threshold. Neuron 15:1-4.

Brenman JE, Chao DS, Gee SH, McGee AW, Craven SE, Santillano DR, Wu Z, Huang F, Xia H, Peters MF, Froehner SC, Bredt DS (1996) Interaction of nitric oxide synthase with the postsynaptic density protein PSD-95 and alpha1-syntrophin mediated by PDZ domains. Cell 84:757-767.

Butz S, Okamoto M, Sudhof TC (1998) A tripartite protein complex with the potential to couple synaptic vesicle exocytosis to cell adhesion in brain. Cell 94:773-782.

Choi DW (1994) Glutamate receptors and the induction of excitotoxic neuronal death. Prog Brain Res 100:47-51.

Craig AM, Wyborski RJ, Banker G (1995) Preferential addition of newly synthesized membrane protein at axonal growth cones. Nature 375:592-594.

Dawson VL, Dawson TM, London ED, Bredt DS, Snyder SH (1991) Nitric oxide mediates glutamate neurotoxicity in primary cortical cultures. Proc Natl Acad Sci USA 88:6368-6371.

During MJ, Symes CW, Lawlor PA, Lin J, Dunning J, Fitzsimons HL, Poulsen D, Leone P, Xu R, Dicker BL, Lipski J, Young D (2000) An oral vaccine against NMDAR1 with efficacy in experimental stroke and epilepsy. Science 287:1453-1460.

Follesa P, Ticku MK (1996) NMDA receptor upregulation: molecular studies in cultured mouse cortical neurons after chronic antagonist exposure. J Neurosci 16:2172-2178.

Furshpan EJ, Potter DD (1989) Seizure-like activity and cellular damage in rat hippocampal neurons in cell culture. Neuron 3:199-207.

Goslin K, Asmussen H, Banker G (1998) Hippocampal neurons in low density culture. In: Culturing nerve cells, pp 000-000. Cambridge, MA: MIT.

Grab DJ, Carlin RK, Siekevitz P (1981) Function of calmodulin in postsynaptic densities. I. Presence of a calmodulin-activatable cyclic nucleotide phosphodiesterase activity. J Cell Biol 89:433-439.

Hall RA, Soderling TR (1997) Differential surface expression and phosphorylation of the $N$-methyl-D-aspartate receptor subunits NR1 and NR2 in cultured hippocampal neurons. J Biol Chem 272:4135-4140.

Hirao K, Hata Y, Ide N, Takeuchi M, Irie M, Yao I, Deguchi M, Toyoda A, Sudhof TC, Takai Y (1998) A novel multiple PDZ domaincontaining molecule interacting with $N$-methyl-Md-aspartate receptors and neuronal cell adhesion proteins. J Biol Chem 273:21105-21110.

Huerta PT, Sun LD, Wilson MA, Tonegawa S (2000) Formation of temporal memory requires NMDA receptors within CA1 pyramidal neurons. Neuron 25:473-480.

Huettner JE, Bean BP (1988) Block of $N$-methyl-md-aspartate-activated current by the anticonvulsant MK-801: selective binding to open channels. Proc Natl Acad Sci USA 85:1307-1311.

Jo K, Derin R, Li M, Bredt DS (1999) Characterization of MALS/ Velis-1, -2, and -3: a family of mammalian LIN-7 homologs enriched at brain synapses in association with the postsynaptic density-95/NMDA receptor postsynaptic complex. J Neurosci 19:4189-4199.

Kakkar R, Raju RV, Sharma RK (1999) Calmodulin-dependent cyclic nucleotide phosphodiesterase (PDE1). Cell Mol Life Sci 55:1164-1186.

Kornau HC, Seeburg PH, Kennedy MB (1997) Interaction of ion channels and receptors with PDZ domain proteins. Curr Opin Neurobiol 7:368-373.

Leonard AS, Hell JW (1997) Cyclic AMP-dependent protein kinase and protein kinase $\mathrm{C}$ phosphorylate $N$-methyl-Md-aspartate receptors at different sites. J Biol Chem 272:12107-12115.

Liao D, Zhang X, O’Brien R, Ehlers MD, Huganir RL (1999) Regulation of morphological postsynaptic silent synapses in developing hippocampal neurons. Nat Neurosci 2:37-43.

Lisman J (1989) A mechanism for the Hebb and the anti-Hebb processes underlying learning and memory. Proc Natl Acad Sci USA 86:9574-9578.

Luscher C, Xia H, Beattie EC, Carroll RC, von Zastrow M, Malenka RC,
Nicoll RA (1999) Role of AMPA receptor cycling in synaptic transmission and plasticity. Neuron 24:649-658.

Marshall J, Molloy R, Moss GW, Howe JR, Hughes TE (1995) The jellyfish green fluorescent protein: a new tool for studying ion channel expression and function. Neuron 14:211-215.

Mayer ML, Westbrook GL, Guthrie PB (1984) Voltage-dependent block by $\mathrm{Mg}^{2+}$ of NMDA responses in spinal cord neurones. Nature 309:261-263.

McDonald JW, Johnston MV (1990) Physiological and pathophysiological roles of excitatory amino acids during central nervous system development. Brain Res Brain Res Rev 15:41-70.

McGee AW, Bredt DS (1999) Identification of an intramolecular interaction between the SH3 and guanylate kinase domains of PSD-95. J Biol Chem 274:17431-17436.

Mohn AR, Gainetdinov RR, Caron MG, Koller BH (1999) Mice with reduced NMDA receptor expression display behaviors related to schizophrenia. Cell 98:427-436.

Mori H, Mishina M (1995) Structure and function of the NMDA receptor channel. Neuropharmacology 34:1219-1237.

Mori H, Manabe T, Watanabe M, Satoh Y, Suzuki N, Toki S, Nakamura K, Yagi T, Kushiya E, Takahashi T, Inoue Y, Sakimura K, Mishina M (1998) Role of the carboxy-terminal region of the GluR epsilon2 subunit in synaptic localization of the NMDA receptor channel. Neuron 21:571-580.

Nakanishi S (1992) Molecular diversity of glutamate receptors and implications for brain function. Science 258:597-603.

Noel J, Ralph GS, Pickard L, Williams J, Molnar E, Uney JB, Collingridge GL, Henley JM (1999) Surface expression of AMPA receptors in hippocampal neurons is regulated by an NSF-dependent mechanism. Neuron 23:365-376.

Obrietan K, Van den Pol AN (1995) Calcium hyperexcitability in neurons cultured with glutamate receptor blockade. J Neurophysiol 73:1524-1536.

Rao A, Craig AM (1997) Activity regulates the synaptic localization of the NMDA receptor in hippocampal neurons. Neuron 19:801-812.

Rothman SM, Olney JW (1995) Excitotoxicity and the NMDA receptor-still lethal after eight years. Trends Neurosci 18:57-58.

Sattler R, Xiong Z, Lu WY, Hafner M, MacDonald JF, Tymianski M (1999) Specific coupling of NMDA receptor activation to nitric oxide neurotoxicity by PSD-95 protein. Science 284:1845-1848.

Seeburg PH (1993) The Trends Neurosci/TiPS Lecture. The molecular biology of mammalian glutamate receptor channels. Trends Neurosci 16:359-365.

Setou M, Nakagawa T, Seog DH, Hirokawa N (2000) Kinesin superfamily motor protein KIF17 and mLin-10 in NMDA receptor-containing vesicle transport. Science 288:1796-1802.

Shi SH, Hayashi Y, Petralia RS, Zaman SH, Wenthold RJ, Svoboda K, Malinow R (1999) Rapid spine delivery and redistribution of AMPA receptors after synaptic NMDA receptor activation. Science 284:1811-1816.

Shin H, Hsueh YP, Yang FC, Kim E, Sheng M (2000) An intramolecular interaction between Src homology 3 domain and guanylate kinaselike domain required for channel clustering by postsynaptic density-95/ SAP90. J Neurosci 20:3580-3587.

Steigerwald F, Schulz TW, Schenker LT, Kennedy MB, Seeburg PH, Kohr G (2000) C-Terminal truncation of NR2A subunits impairs synaptic but not extrasynaptic localization of NMDA receptors. J Neurosci 20:4573-4581.

Tingley WG, Ehlers MD, Kameyama K, Doherty C, Ptak JB, Riley CT, Huganir RL (1997) Characterization of protein kinase A and protein kinase C phosphorylation of the $N$-methyl-md-aspartate receptor NR1 subunit using phosphorylation site-specific antibodies. J Biol Chem 272:5157-5166.

Tsien JZ, Huerta PT, Tonegawa S (1996) The essential role of hippocampal CA1 NMDA receptor-dependent synaptic plasticity in spatial memory. Cell 87:1327-1338.

Turrigiano GG (1999) Homeostatic plasticity in neuronal networks: the more things change, the more they stay the same. Trends Neurosci 22:221-227.

Turrigiano GG, Leslie KR, Desai NS, Rutherford LC, Nelson SB (1998) Activity-dependent scaling of quantal amplitude in neocortical neurons. Nature 391:892-896.

Wechsler A, Teichberg VI (1998) Brain spectrin binding to the NMDA receptor is regulated by phosphorylation, calcium and calmodulin. EMBO J 17:3931-3939.

Westphal RS, Tavalin SJ, Lin JW, Alto NM, Fraser ID, Langeberg LK, Sheng M, Scott JD (1999) Regulation of NMDA receptors by an associated phosphatase-kinase signaling complex. Science 285:93-96.

Wyszynski M, Lin J, Rao A, Nigh E, Beggs AH, Craig AM, Sheng M (1997) Competitive binding of alpha-actin and calmodulin to the NMDA receptor. Nature 385:439-442.

Zhao AZ, Yan C, Sonnenburg WK, Beavo JA (1997) Recent advances in the study of $\mathrm{Ca}^{2+} / \mathrm{CaM}$-activated phosphodiesterases: expression and physiological functions. Adv Second Messenger Phosphoprotein Res 31:237-251. 